\title{
Pulmonary absorption and elimination of ethylene glycol monoethyl ether acetate in man
}

\author{
D GROESENEKEN, H VEULEMANS, R MASSCHELEIN, E VAN VLEM
}

From the Laboratorium voor Arbeidshygiëne en -toxicologie, Afdeling Arbeids- en Verzekeringsgeneeskunde, $K U$ Leuven B-3000 Leuven, Belgium

ABSTRACT Ten male volunteers were exposed to ethylene glycol monoethyl ether acetate (EGEEAc) under various conditions of exposure and physical workload. As exposure proceeded, retention, atmospheric clearance, and uptake rate declined slowly to reach steady state levels after three to four hours. Retention increased as a consequence of higher exposure concentrations and of physical workload performed during exposure. Uptake rate was higher as exposure concentration or pulmonary ventilation rate, or both, increased. Subject related factors such as pulmonary ventilation, cardiac output, height, and body fat content also determined individual uptake. During exposure, partial respiratory elimination of EGEE was observed. This finding confirms the hypothesis that EGEE-Ac is first converted to EGEE by (plasma) esterases. The amount of EGEE eliminated at steady state levels correlated more with uptake rate of EGEE-Ac than with exposure concentration. Respiratory elimination of unmetabolised EGEE-Ac accounted for $\leqslant 0.5 \%$ of total body uptake. The elimination curves were biexponential indicating that at least two pharmacological compartments are involved. Postexposure breath concentrations were higher as total body uptake increased. Several observations may indicate that the hydrolysis of the ester moiety of EGEE-Ac is hindered by the presence of the natural esterase substrates. With increasing plasma concentrations, however, EGEE-Ac competed more favourably for the available esterase.

Since the toxicity of ethylene glycol ethers became better understood, ${ }^{12}$ research on their toxicology and pharmacology has intensified. Several metabolic studies confirmed the presence of the respective alkoxyacetic acid, free or conjugated with glycine, in the urine of exposed animals. ${ }^{3-6}$ Respiratory elimination of the parent compound is only a minor route to excretion. Pulmonary and transcutaneous absorption of ethylene glycol monoethyl ether acetate was very fast in beagle dogs. ${ }^{6}$

Recently, we exposed male volunteers to the ethyl ether of ethylene glycol (EGEE) under controlled conditions of exposure concentration and physical workload. ${ }^{7}$ A high retention, reaching a steady state level immediately after the start of the exposure, was observed. The rate of uptake was directly related to the exposure concentration and parameters of transport mechanisms (pulmonary ventilation and cardiac output). Respiratory elimination of unmetabolised EGEE was small ( $\leqslant 0.4 \%$ of total body uptake), in

Accepted 8 July 1986 agreement with the observations from animal studies. ${ }^{3-6}$ Moreover, ethoxyacetic acid was detected in the urine during and up to 42 hours after the exposure. ${ }^{8}$ At any time, the urinary excretion rate of ethoxyacetic acid was proportional to the amount of EGEE absorbed.

The ethyl ether of ethylene glycol acetate (EGEEAc) is thought to be converted to EGEE by (plasma) esterases as soon as it is absorbed. ${ }^{6}$ Consequently, both solvents should have similar pharmacokinetics and we have investigated the respiratory uptake and elimination of EGEE-Ac under the same conditions as our previous study on EGEE.

\section{Subjects and methods}

\section{SUBJECTS}

Ten healthy male volunteers (aged 21-30) agreed to participate in the study after full information and a written consent. All subjects had a normal lung function profile $\left(\mathrm{FEV}_{1}, \mathrm{VC}, \mathrm{TLC}\right)$. Before and after the study, blood was withdrawn for the determination of blood cell count, haematocrit, haemoglobin, hap- 
Table 1 General characteristics of the subjects (means $\pm S E M$ )

\begin{tabular}{|c|c|c|c|}
\hline & $\begin{array}{l}\text { Group 1 } \\
\text { (resting) } \\
(n=5)\end{array}$ & $\begin{array}{l}\text { Group } 2 \\
\text { (exercising) } \\
(n=5)\end{array}$ & $t(p)$ \\
\hline $\begin{array}{l}\text { Age (years) } \\
\text { Weight (kg) } \\
\text { Height (cm) } \\
\% \text { Body fat }\end{array}$ & $\begin{array}{l}25 \pm 2 \\
68 \cdot 2 \pm 3 \cdot 8 \\
181 \cdot 5 \pm 2 \cdot 0 \\
9 \cdot 0 \pm 0 \cdot 4\end{array}$ & $\begin{array}{l}26 \pm 2 \\
64.3 \pm 2.0 \\
178.5 \pm 2.0 \\
10.7 \pm 1.4\end{array}$ & $\begin{array}{l}0.18 \text { (NS) } \\
0.89 \text { (NS) } \\
1.05 \text { (NS) } \\
1.18 \text { (NS) }\end{array}$ \\
\hline
\end{tabular}

toglobin, LDH, GOT, GPT, and $\gamma$-GT. In no case were significant disorders observed.

\section{EXPERIMENTAL CONDITIONS}

The subjects were randomly assigned into two groups (table 1 ) comparable $(t \leqslant 1 \cdot 23$; NS) for age, weight, height, and body fat content, calculated from the measurement of skinfold thickness at four different sites (biceps, triceps, subscapula, and suprailiaca). ${ }^{9}$ All subjects performed three experiments according to their group assignment. The first group was exposed at rest to respectively $14 \mathrm{mg} / \mathrm{m}^{3}, 28 \mathrm{mg} / \mathrm{m}^{3}$, and $50 \mathrm{mg} / \mathrm{m}^{3}$ EGEE-Ac. The second group was exposed to $28 \mathrm{mg} / \mathrm{m}^{3}$ under resting conditions and during standard physical exercise at $30 \mathrm{~W}$ and $60 \mathrm{~W}$. Between the experimental sessions the subjects remained unexposed for at least one week (usually two or three weeks).

The exposure period in each experiment was standardised to four hours, equivalent to half a work shift. At the end of every hour, a short break of 10 minutes was inserted. The exposure concentrations were chosen to be near to the present day threshold limit value of EGEE-Ac $\left(27 \mathrm{mg} / \mathrm{m}^{3}\right) \cdot{ }^{10}$ The experiments at rest were held with the exposed subjects sitting in an arm chair, whereas the standard physical exercises were performed on a bicycle ergometer (Mynhardt, type KEM2) at a constant pedal frequency $(50 / \mathrm{min})$.

\section{MEASUREMENTS DURING AND AFTER EXPOSURE} Exposure concentrations of EGEE-Ac, generated from a syringe injection system as described elsewhere, ${ }^{11}$ were calibrated before each experiment and checked every hour. Samples of mixed expired air were taken every 10 minutes during exposure and with a decreasing frequency after exposure finished. The procedure for air sampling and analysis may be found elsewhere. ${ }^{7}$ During and after exposure, ECG (Simpliscriptor EK 100, Hellige), pulmonary ventilation rate $\left(\dot{\mathrm{V}}_{\mathrm{E}}\right)$, and oxygen consumption $\left(\dot{\mathrm{V}}_{\mathrm{O}_{2}}\right)$ (Oxycon analyzer, Mynhardt) were continuously monitored. $\dot{\mathrm{V}}_{\mathrm{E}}$ and $\dot{\mathrm{V}}_{\mathrm{O}_{2}}$ were recorded immediately before air sampling, whereas heart rate (based on 10 $R-R$ intervals on ECG) and respiratory frequency were determined during sampling.
Groeseneken, Veulemans, Masschelein, Van Vlem

STATISTICAL ANALYSIS

Data were analysed using three way ANOVA wit高 experimental condition, exposure time, and subject as the main sources of variation. Where appropriates analysis of covariance was introduced. Single and multiple linear regression analysis were used to deter흘. mine the contributions of subject related parameters

Results

\section{RESPIRA TORY UPTAKE}

Absorption and exposure time

For all experimental conditions, retention $\left(\mathbf{R}_{\mathbf{E}}\right) \stackrel{\mathrm{N}}{\mathrm{N}}$ atmospheric clearance $\left(\mathrm{Cl}_{\mathrm{atm}}\right)$, and uptake rate $\left(\mathrm{U}_{\mathscr{D}}\right.$ decreased as the exposure proceeded $\left(F_{t} \geqslant 1.95 ; p<\right.$ 0.05 or less) (fig 1) and a steady state level seemed to be reached only after three to four hours. When physer ical exercise was performed during exposure, $\mathbf{R}_{\mathrm{E}} \omega$ $\mathrm{Cl}_{\text {atm }}$, and $\mathrm{U}$ decreased more slowly as indicated by $\alpha_{0}^{\circ}$ significant interaction between the level of exercise and the exposure time $\left(F_{i} \geqslant 1.71 ; p<0.05\right.$ or less $)$

Our observations are in agreement with those of Guest $e t$ al who found an increase in expired concentration and a concomitant decrease of retention wheno beagle dogs were exposed to $270 \mathrm{mg} / \mathrm{m}^{3}$ EGEE-Ac. $\stackrel{\circ}{\sim}$

\section{Absorption and exposure concentration}

As the exposure concentration increased, an increase in $R_{E}$ was observed $\left(F_{c}=5.50 ; p<0.05\right)$. At stead state conditions, $R_{E}$ averaged $0.53 \pm 0.09$ for 1 क $\mathrm{mg} / \mathrm{m}^{3}$ EGEE-Ac, $0.57 \pm 0.07$ for $28 \mathrm{mg} / \mathrm{m}^{3}$, an $\stackrel{8}{2}$ $0.62 \pm 0.05$ for $50 \mathrm{mg} / \mathrm{m}^{3}$. This observation is rathe $\overrightarrow{\overrightarrow{0}}$ unexpected. When the capacity for metabolic clear ance becomes saturated with higher exposure concen trations, a more rapid increase in bloos. concentrations and consequently a decrease in reteno tion would result such as has been observed for $\$$ series of non-polar solvents. ${ }^{12-14}$ On the other hand; retention may remain unchanged when the capacity. for metabolic clearance does not reach saturation å observed for EGEE. ${ }^{7}$

Despite an increase of $R_{E}, C_{\text {atm }}$ did not change when exposure concentration was higher $\left(F_{c}=0.94\right.$ NS). A possible explanation could be a concomitant. decrease in pulmonary ventilation rate $\left(\dot{\mathrm{V}}_{\mathbf{E}}\right)$. Althoug $\dot{\mathrm{V}}_{\mathrm{E}}$ did not differ $(\mathrm{F}=0.68$; NS $)$ at higher exposure concentrations (table 2), $\mathrm{Cl}_{\text {atm }}$ showed the expected increase after adjustment for $\dot{V}_{E} \quad\left(F=37 . \Phi_{W}\right.$ $\mathrm{p}<0.001$ ).

$\dot{U}$ increased as the inhaled concentration increased $\left(F_{c}=128.2 ; p<0.001\right)$. Since $\dot{U}$ was calculated af $R_{E} \times \dot{V}_{E} \times C_{l}$, and since $R_{E}$ also increased at highef inhaled concentrations, $\dot{U}$ is not a simple linear function of $C_{1}$. Nevertheless, the linear regression of $\dot{U} \vec{Q}$ $\mathrm{C}_{\mathrm{I}}$ yields a satisfactory approximation:

$\dot{U}(\mu \mathrm{g} / \mathrm{min})=8.45 \times \mathrm{C}_{\mathrm{I}}(\mu \mathrm{g} / \mathrm{l}) \quad \mathrm{r}=0.93 ; \mathrm{p}<0.001 \stackrel{\mathrm{Q}}{\stackrel{\mathrm{D}}{\mathrm{O}}}$ 

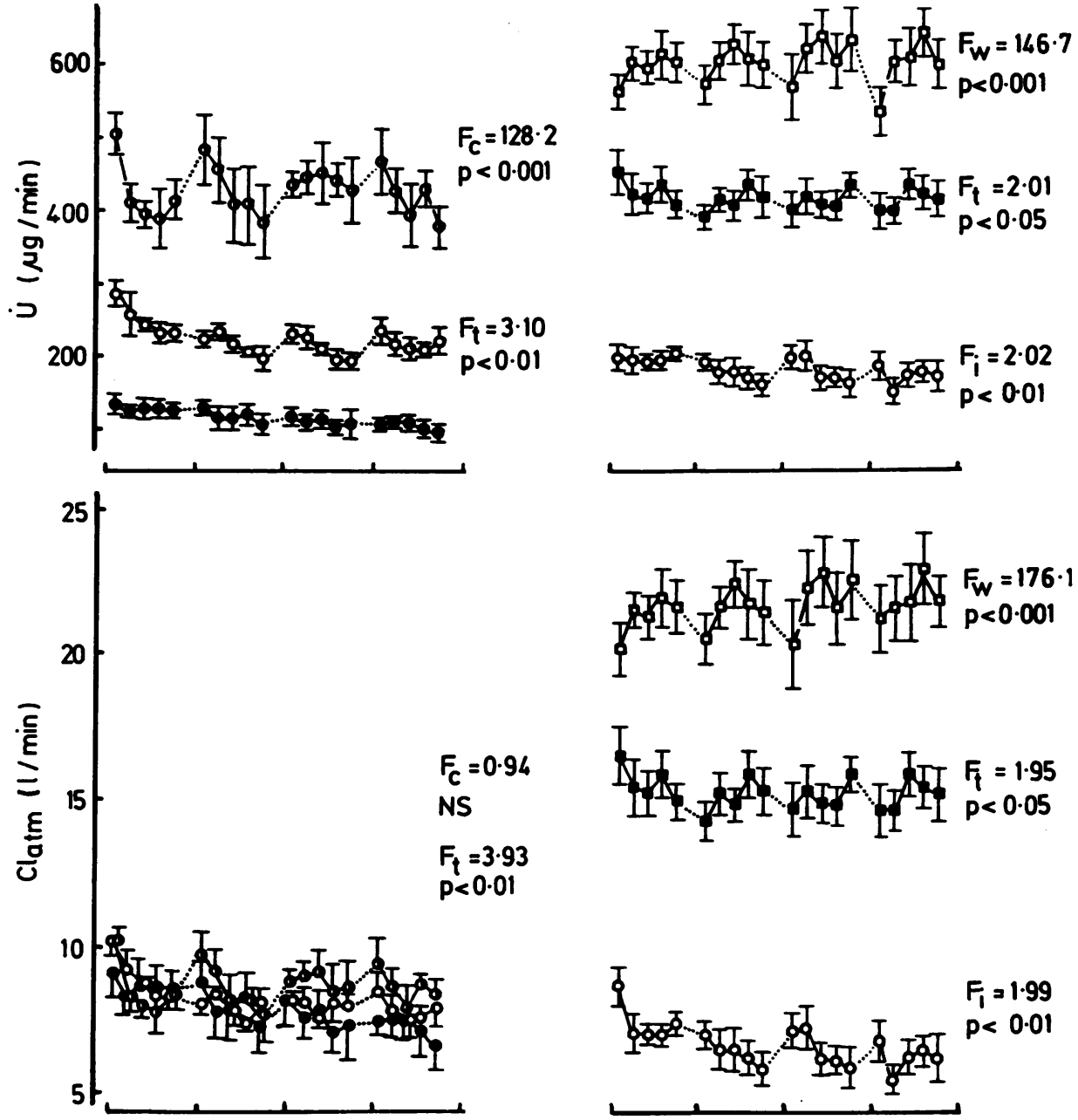

率
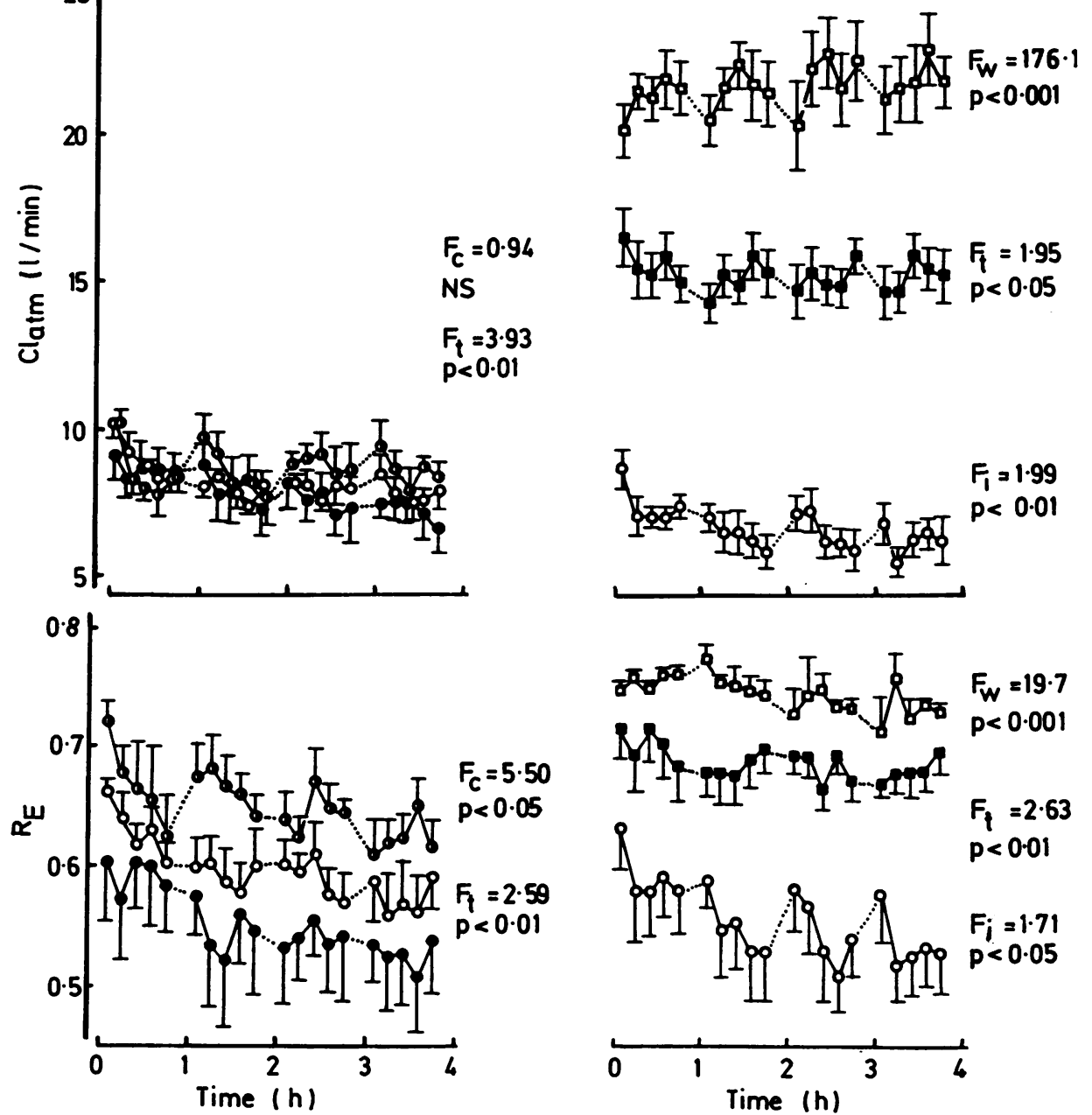

$F_{t}=3.93$

$P<0.01$

Fig 1 Retention $\left(R_{E}\right)$, atmospheric clearance $\left(C l_{a t m}\right)$, and uptake rate $(\dot{U})$ during exposure to EGEE-Ac under various conditions: $14 \mathrm{mg} / \mathrm{m}^{3}(\odot), 28 \mathrm{mg} / \mathrm{m}^{3}(\mathrm{O})$, and $50 \mathrm{mg} / \mathrm{m}^{3}$ (O) at rest or $28 \mathrm{mg} / \mathrm{m}^{3}$ at $30 \mathrm{~W}(\square)$ and $60 \mathrm{~W}$ (口). Data are means \pm SEM for five subjects. Statistical data are F-ratios from three way ANOVA: $c=$ exposure concentration, $w=$ workload level, $t=$ time, and $i=$ interaction between $w$ and $t$.

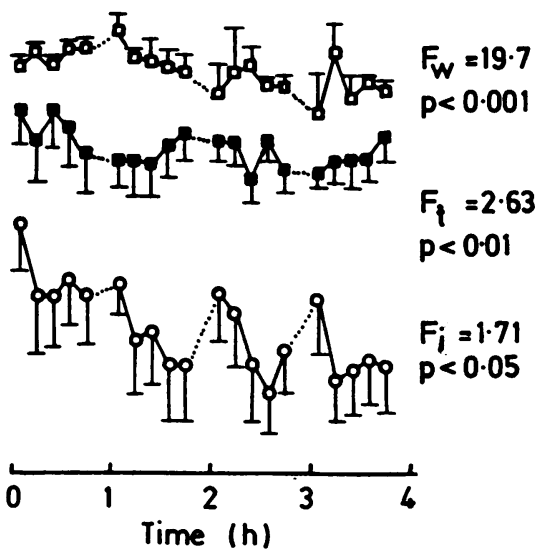


Table 2 Cardiopulmonary data during exposure to EGEE-Ac (means \pm SEM for five subjects)

\begin{tabular}{|c|c|c|c|c|}
\hline Exposure conditions & $\dot{V}_{E}(l / \min )$ & $\dot{V}_{\mathrm{O}_{2}}(l / \min )$ & $f\left(\min ^{-1}\right)$ & $H R\left(\min ^{-1}\right)$ \\
\hline $\begin{array}{ll}\text { Group 1: } & \\
14 \mathrm{mg} / \mathrm{m}^{3}: & 0 \mathrm{~W} \\
28 \mathrm{mg} / \mathrm{m}^{3}: & 0 \mathrm{~W} \\
50 \mathrm{mg} / \mathrm{m}^{3}: & 0 \mathrm{~W}\end{array}$ & $\begin{array}{l}14.4 \pm 0.9 \\
13.7 \pm 0.8 \\
13.2 \pm 1.1 \\
F=0.68(\mathrm{NS})\end{array}$ & $\begin{array}{l}0.26 \pm 0.02 \\
0.25 \pm 0.02 \\
0.24 \pm 0.03 \\
F=0.69(\mathrm{NS})\end{array}$ & $\begin{array}{l}14 \cdot 8 \pm 1 \cdot 3 \\
14 \cdot 2 \pm 1 \cdot 4 \\
14 \cdot 2 \pm 1 \cdot 6 \\
F=0 \cdot 24(\mathrm{NS})\end{array}$ & $\begin{array}{l}70 \pm 4 \\
72 \pm 3 \\
72 \pm 4 \\
F=0 \cdot 14(\mathrm{NS})\end{array}$ \\
\hline $\begin{array}{l}\text { Group 2: } \\
28 \mathrm{mg} / \mathrm{m}^{3}: 0 \mathrm{~W} \\
28 \mathrm{mg} / \mathrm{m}^{3}: 30 \mathrm{~W} \\
28 \mathrm{mg} / \mathrm{m}^{3}: 60 \mathrm{~W}\end{array}$ & $\begin{array}{l}12 \cdot 2 \pm 1 \cdot 1 \\
22 \cdot 3 \pm 1 \cdot 1 \\
29 \cdot 1 \pm 1 \cdot 3 \\
F=129 \cdot 7 ; p<0.001\end{array}$ & $\begin{array}{l}0.22 \pm 0.02 \\
0.54 \pm 0.04 \\
0.81 \pm 0.05 \\
F=115.9 ; p<0.001\end{array}$ & $\begin{array}{l}14 \cdot 2 \pm 1 \cdot 1 \\
15 \cdot 1 \pm 1 \cdot 4 \\
16 \cdot 0 \pm 1 \cdot 8 \\
F=1 \cdot 09(\mathrm{NS})\end{array}$ & $\begin{array}{c}69 \pm 3 \\
97 \pm 3 \\
116 \pm 5 \\
F=56 \cdot 2 ; p<0.001\end{array}$ \\
\hline
\end{tabular}

Absorption and physical exercise

Compared with the resting condition, $\mathrm{Cl}_{\mathrm{atm}}$ $\left(\mathrm{F}_{\mathrm{w}}=176.1 ; \quad \mathrm{p}<0.001\right)$ and consequently UU $\left(F_{w}=146.7 ; p<0.001\right)$ increased when physical effort was exerted during exposure. The increase of $\mathrm{Cl}_{\text {atm }}$ and $\dot{U}$ was due not only to a higher $\dot{\mathrm{V}}_{\mathbf{E}}$ $(\mathrm{F}=129.7 ; \mathrm{p}<0.001)$ but also to a proportional increase of $R_{E}\left(F_{w}=19.7 ; p<0.001\right)$. An increased retention was also observed in the exposure to EGEE during physical exercise. ${ }^{7}$

A linear relation between $\dot{U}$ and $\dot{V}_{E}$ was found despite the contribution of an increased $R_{E}$ on higher $\dot{\mathrm{V}}_{\mathbf{E}}$ :

$$
\dot{U}(\mu \mathrm{g} / \mathrm{min})=19.64 \times \dot{\mathrm{V}}_{\mathrm{E}}(\mathrm{l} / \mathrm{min}) \mathrm{r}=0.96 ; \mathrm{p}<0.001
$$

\section{Subject related factors affecting individual uptake}

Since both groups performed a common experiment $\left(28 \mathrm{mg} / \mathrm{m}^{3}\right.$ EGEE-Ac at rest), individual differences in respiratory uptake were first studied using data from this experiment. Although the exposure concentration was identical in both groups $(F=0.35 ; N S), R_{E}$, $\mathrm{Cl}_{\mathrm{atm}}$, and $\dot{U}$ were significantly lower for the group with variable workloads. This could not be explained by different body weight, height, and body fat content (table 1). On the other hand, the subjects of the "exercising" group showed lower $\dot{V}_{E}(F=20.9 ; p<0.001)$,

Table 3 Pearson's correlation matrix of respiratory uptake data

\begin{tabular}{|c|c|c|c|}
\hline Variable & $R_{E}$ & $C l_{a t m}(l / m i n)$ & $\dot{U}(\mu g / \min )$ \\
\hline 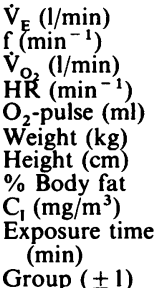 & $\begin{array}{l}0.52^{* *} \\
0 \cdot 18^{* *} \\
0.56^{* *} \\
0.50^{* *} \\
0.51^{* *} \\
- \\
- \\
0.14^{* *} \\
0.35^{* *} \\
-0.16^{* *} \\
-0.28^{* *}\end{array}$ & $\begin{array}{l}0.97^{* *} \\
0.26^{* *} \\
0.95^{* *} \\
0.85^{* *} \\
0.87^{* *} \\
- \\
-0.18^{* *} \\
0.18^{* *} \\
- \\
- \\
0.56^{* *}\end{array}$ & $\begin{array}{l}0.72^{* *} \\
0.18^{* *} \\
0.71^{* *} \\
0.64^{* *} \\
0.65^{* *} \\
\overline{0.1} \\
0.11^{*} \\
0.54^{* *} \\
- \\
0.33^{* *}\end{array}$ \\
\hline
\end{tabular}

lower $\dot{\mathrm{V}}_{\mathrm{O}_{2}}(\mathrm{~F}=17.0 ; \mathrm{p}<0.001)$, and lower heart rate욜 $(\mathrm{F}=6.68 ; \mathrm{p}<0.01)$. When adjusted for each of these variables separately, however, $\mathbf{R}_{\mathbf{E}} \cdot \mathrm{Cl}_{\mathrm{atm}}$, and $\dot{U}$ rẹt mained lower for the exercising group $(F \geqslant 9.7 \%$, $\mathrm{p}<0.01$ or less).

To study the subject related parameters more genetally, single regression analysis on pooled data was used (table 3). A dummy variable for group was introduced: +1 for the "resting" group and -1 for the exercising group. $\mathrm{R}_{\mathrm{E}}, \mathrm{Cl}_{\mathrm{atm}}$, and U were positively related to the cardiopulmonary variables $\left(\dot{\mathrm{V}}_{\mathrm{E}}, \dot{\mathrm{V}}_{\mathbf{O}_{20}}\right.$ respiratory frequency, heart rate, and oxygen pulse $-\cdot$ $\dot{\mathrm{V}}_{\mathrm{O}_{2}} / \mathrm{HR}$ ) and to the body fat content. The dumm罗 variable was also a significant contributing factor. I送 multiple linear regression analysis, however, using step up procedure, the correlation with "group" dif not persist (table 4). Individual respiratory uptake of EGEE-Ac is thus mainly governed by transport mechanisms (pulmonary ventilation rate and cardiac ou? put, measured by oxygen pulse) and by the

Table 4 Multiple linear regression coefficients of respiratory uptake data

\begin{tabular}{|c|c|c|c|}
\hline Variable & $R_{E}$ & $C l_{a t m}(l / m i n)$ & $\dot{U}(\mu g / \min )$ \\
\hline$\dot{\mathrm{V}}_{\mathrm{E}}(1 / \mathrm{min})$ & $\begin{array}{c}0.0058 \\
\left(r=0 \cdot 25^{* *}\right)\end{array}$ & $\begin{array}{c}0.783 \\
(r=0.89 * *)\end{array}$ & $\begin{array}{c}22 \cdot 35 \\
\left(r=0.88^{* *}\right.\end{array}$ \\
\hline$f\left(\min ^{-1}\right)$ & - & $\left(r=0.10^{*}\right)$ & $11-000$ \\
\hline $\mathrm{O}_{2}$-pulse $(\mathrm{ml})$ & $\begin{array}{c}0.0152 \\
\left(r=0.17^{* *}\right)\end{array}$ & $\begin{array}{c}0.264 \\
\left(r=0.17^{* *}\right)\end{array}$ & $\begin{array}{c}6.2 \\
\left(r=0.13^{*}\right)\end{array}$ \\
\hline Weight (kg) & - & $\begin{array}{l}-0.028 \\
\left(r=0.13^{*}\right)\end{array}$ & - \\
\hline Height $(\mathrm{cm})$ & $\begin{array}{c}0.0049 \\
\left(r=0.27^{* *}\right)\end{array}$ & $\begin{array}{c}0.088 \\
\left(r=0.25^{* *}\right)\end{array}$ & $\begin{array}{c}1.61 \\
\left(r=0.17^{*}\right.\end{array}$ \\
\hline$\%$ Body fat & $\begin{array}{c}0.0073 \\
\left(r=0.22^{* *}\right)\end{array}$ & $\begin{array}{c}0.121 \\
\left(r=0.20^{* *}\right)\end{array}$ & $\begin{array}{c}2.12 \\
\left(r=0.12^{*}\right)\end{array}$ \\
\hline$C_{I}\left(\mathrm{mg} / \mathrm{m}^{3}\right)$ & $\begin{array}{c}0.0036 \\
\left(r=0.055^{* *}\right)\end{array}$ & $\begin{array}{c}0.051 \\
(r=0.48 * *)\end{array}$ & $\begin{array}{c}10.28 \\
\left(r=0.96^{* *}\right.\end{array}$ \\
\hline $\begin{array}{l}\text { Exposure time } \\
\text { (min) }\end{array}$ & $\begin{array}{l}-0.0003 \\
\left(r=0.27^{* *}\right)\end{array}$ & $\begin{array}{c}-0.004 \\
\left(r=0.24^{* *}\right)\end{array}$ & $\begin{array}{c}-0.09 \\
\left(r=0.17^{* *}\right)\end{array}$ \\
\hline Group $( \pm 1)$ & - & - & - \\
\hline $\begin{array}{l}\text { Constant } \\
\text { Overall correlation }\end{array}$ & -0.57 & $-20 \cdot 3$ & -685 \\
\hline coefficient & $0 \cdot 75^{* *}$ & $0.98^{* *}$ & $0.98^{* *}$ \\
\hline
\end{tabular}



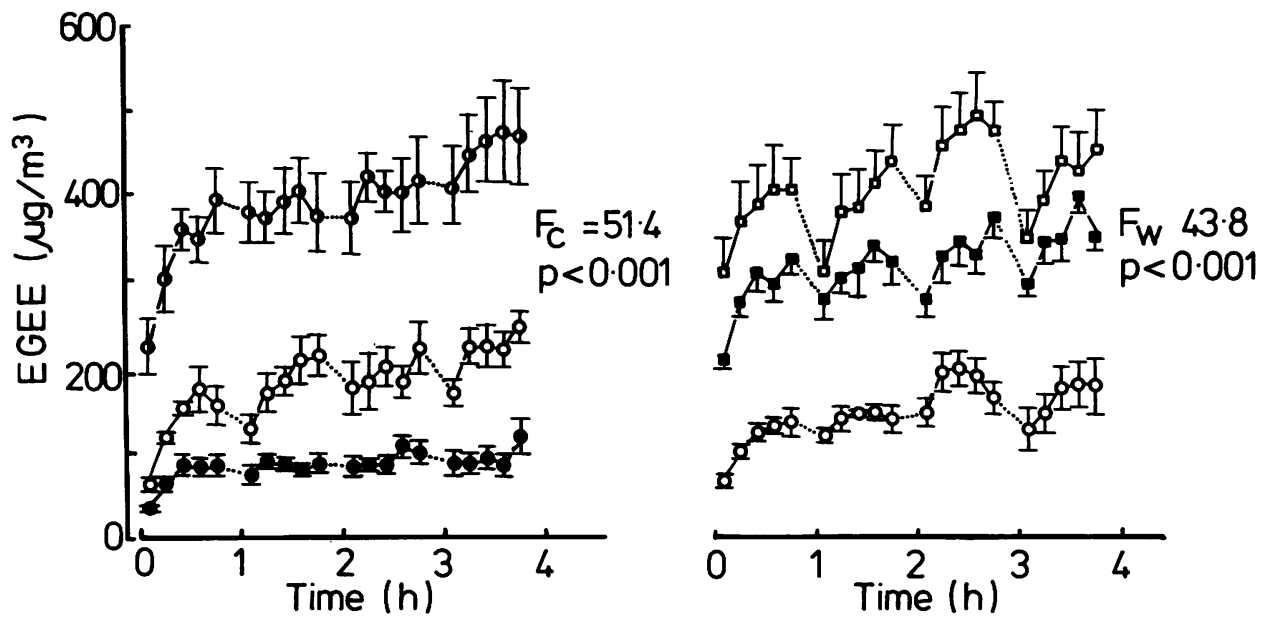

Fig 2 Respiratory elimination of EGEE during exposure to EGEE-Ac under various conditions. Data are means $\pm S E M$ for five subjects. Symbols are as in fig 1.

distribution volume, indicated by anthropometric data.

\section{RESPIRATORY ELIMINATION OF EGEE DURING} EXPOSURE TO EGEE-AC

Samples of mixed expired air during exposure to EGEE-Ac contained not only EGEE-Ac but also small amounts of EGEE; EGEE was below detection limit in inspired air. Analysis of concentrated solutions of EGEE-Ac in methanol showed that EGEE was present only as a trace impurity $(0.05 \pm 0.02 \%$ $\mathrm{w} / \mathrm{w})$.

The EGEE present in samples of mixed expired air may therefore be considered to result from metabolic conversion of EGEE-Ac by esterases. The amount of EGEE increased $(F \geqslant 13.6 ; p<0.001)$ as exposure proceeded under all experimental conditions. Moreover, the expired EGEE increased proportionally with a higher uptake of EGEE-Ac as a consequence of higher exposure concentration $\left(F_{c}=51.4 ; p<0.001\right)$
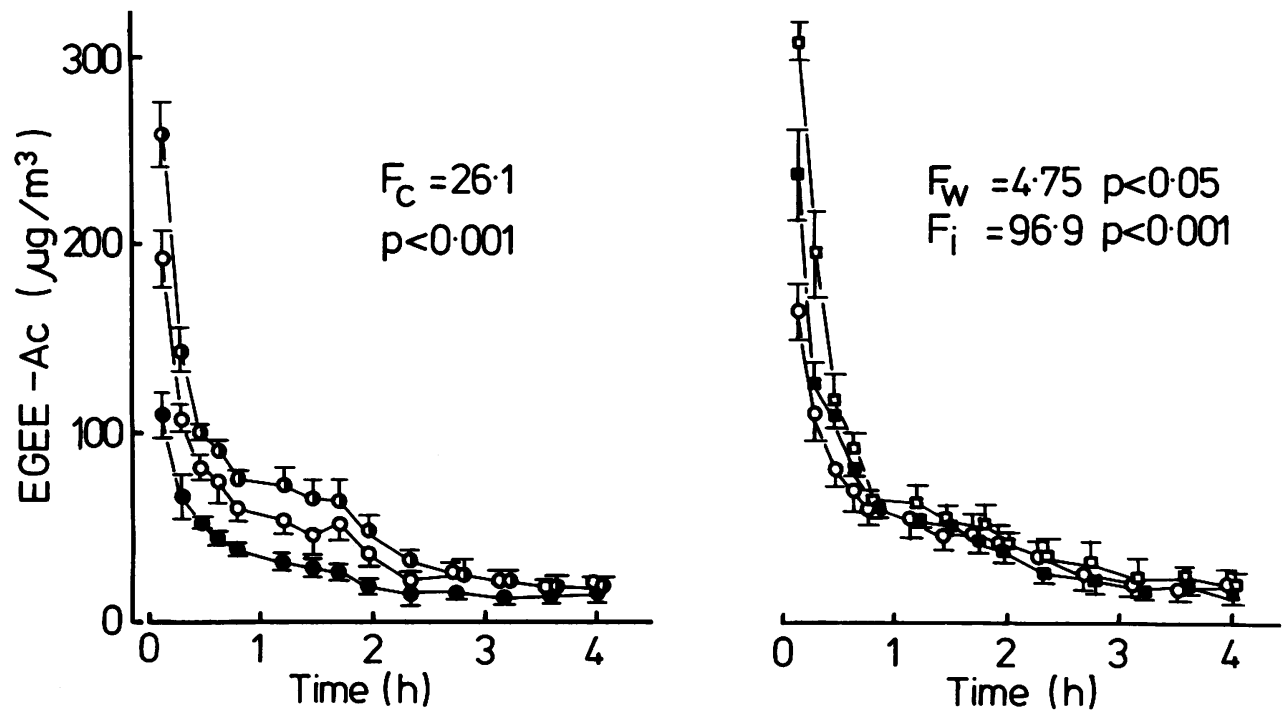

Fig 3 Respiratory elimination of EGEE-Ac after exposure was stopped. Data are means $\pm S E M$ for five subjects. Symbols are as in fig 1. 
or of physical effort $\left(F_{w}=43.8 ; p<0.001\right)$ (fig 2). At steady state conditions, a linear relation between expired EGEE and uptake rate of EGEE-Ac was observed:

$$
\begin{aligned}
& \operatorname{EGEE}\left(\mu \mathrm{g} / \mathrm{m}^{3}\right)=0.816 \times \dot{U}(\mu \mathrm{g} / \mathrm{min}) \\
& \mathrm{r}=0.79 ; \mathrm{p}<0.001
\end{aligned}
$$

The correlation between EGEE and uptake rate proved noticeably better than between EGEE and exposure concentration $(r=0.58 ; p<0.001)$ as a result of a more than proportional increase of EGEE with $\mathrm{C}_{\mathrm{l}}$. This was indicated by significant contributions of higher power terms in polynomial regression analysis.

EGEE appeared with a rate constant of $0.077 \pm 0.013 \mathrm{~min}^{-1}$ for the experiments at rest and of $0.217 \pm 0.023 \mathrm{~min}^{-1}$ for the experiments during physical exercise. From the rate constants at rest, a half life of eight to 11 minutes could be calculated. When physical work is exerted, the rate of appearance of EGEE seemed to be higher.

\section{RESPIRATORY ELIMINATION OF EGEE-AC AFTER EXPOSURE}

\section{Time course of respiratory elimination}

Postexposure breath concentrations of EGEE-Ac declined rapidly during the first minutes after the cessation of exposure. Thereafter a much slower decrease was observed during the following four hours (fig 3 ). This slow decrease could best be represented by a regression equation containing at least two exponential terms:

$$
C_{E}=128 \mathrm{e}^{-0.107 t}+54 \mathrm{e}^{-0.0078 \mathrm{t}}
$$

after exposure at rest to $14 \mathrm{mg} / \mathrm{m}^{3}(\mathrm{n}=5)$

$$
\mathrm{C}_{\mathrm{E}}=232 \mathrm{e}^{-0.112 \mathrm{t}}+86 \mathrm{e}^{-0.0072 \mathrm{t}}
$$

after exposure at rest to $28 \mathrm{mg} / \mathrm{m}^{3}(\mathrm{n}=10)$

$$
C_{E}=414 \mathrm{e}^{-0.139 t}+119 \mathrm{e}^{-0.0080 \mathrm{t}}
$$

after exposure at rest to $50 \mathrm{mg} / \mathrm{m}^{3}(\mathrm{n}=5)$

$$
\mathrm{C}_{\mathrm{E}}=332 \mathrm{e}^{-0 \cdot 119 \mathrm{t}}+108 \mathrm{e}^{-0.0083 \mathrm{t}}
$$

after exposure at $30 \mathrm{~W}$ to $28 \mathrm{mg} / \mathrm{m}^{3}(\mathrm{n}=5)$

$$
\mathrm{C}_{\mathrm{E}}=428 \mathrm{e}^{-0.109 \mathrm{t}}+93 \mathrm{e}^{-0.0075 \mathrm{t}}
$$

after exposure at $60 \mathrm{~W}$ to $28 \mathrm{mg} / \mathrm{m}^{3}(\mathrm{n}=5)$
Groeseneken, Veulemans, Masschelein, Van Vlem

Postexposure breath concentrations increased respiratory uptake was higher as a consequence of higher exposure concentrations $\left(F_{c}=26 \cdot F^{*}\right.$ $\mathrm{p}<0.001)$ and of physical exercise $\left(\mathrm{F}_{\mathrm{w}}=4.75\right.$ $\mathrm{p}<0.05$ ). The elimination curves, however, after physical exercise seemed to converge as indicated bo a significant interaction between workload level an time $\left(F_{i}=96.9 ; p<0.001\right)$. Higher concentrations of EGEE-Ac after physical exercise could therefore found only during the first 30-60 minutes of respiras tory elimination.

\section{Total respiratory elimination}

The amount of expired EGEE-Ac was calculated by the integration of the elimination curves $\left(C_{E} / \dot{V}_{E}\right.$ ver sus time). As the total body uptake increased, the amount of EGEE-Ac eliminated increased $(F=17.997$ $\mathrm{p}<0.001$ for higher exposure concentration $F=6.3 ; p<0.05$ for the experiments during physical exercise). Nevertheless, the recovery of expired EGEE-Ac decreased $(F \geqslant 7.4 ; p<0.05)$ as the totat body uptake increased (table 5). Nevertheless, respiras tory elimination of EGEE-Ac remained a minor route of excretion since only $\leqslant 0 \cdot 5 \%$ of uptake was recow ered.

Multiple linear regression analysis of the pooled data showed that the amount of EGEE-Ac eliminate was related only to total body uptake (TBU), body faf content (BFC), and $\dot{\mathrm{V}}_{\mathrm{E}}$ during elimination:

EGEE-Ac $_{\mathrm{el}}(\mu \mathrm{g})=89.2+10.61 \dot{\mathrm{V}}_{\mathrm{E}}(\mathrm{l} / \mathrm{min})$ $1 \cdot 10 \mathrm{TBU}(\mathrm{mg})+5.75 \mathrm{BFC}$

$$
\begin{array}{ccc}
r=0.55 & r=0.74 \quad & r=0.36 \\
p<0.001 \quad & p<0.001 \quad p<0.01 \\
R=0.84 ; \quad p<0.001
\end{array}
$$

\begin{tabular}{|c|c|c|c|}
\hline Exposure conditions & Total body uptake (mg) & Amount expired ( $\mu \mathrm{g})$ & Recovery (\%) \\
\hline $\begin{array}{ll}\text { Group 1: } & \\
14 \mathrm{mg} / \mathrm{m}^{3}: & 0 \mathrm{~W} \\
28 \mathrm{mg} / \mathrm{m}^{3}: & 0 \mathrm{~W} \\
50 \mathrm{mg} / \mathrm{m}^{3}: & 0 \mathrm{~W}\end{array}$ & $\begin{array}{l}23 \cdot 3 \pm 2 \cdot 0 \\
44.9 \pm 1 \cdot 3 \\
85 \cdot 1 \pm 5 \cdot 5 \\
F=128 \cdot 2 ; p<0.001\end{array}$ & $\begin{array}{l}96 \pm 7 \\
158 \pm 16 \\
202 \pm 16 \\
F=17.9 ; p<0.001\end{array}$ & $\begin{array}{l}0.43 \pm 0.04 \\
0.36 \pm 0.04 \\
0.24 \pm 0.03 \\
F=7.4 ; p<0.05\end{array}$ \\
\hline $\begin{array}{l}\text { Group 2: } \\
28 \mathrm{mg} / \mathrm{m}^{3}: 0 \mathrm{~W} \\
28 \mathrm{mg} / \mathrm{m}^{3}: 30 \mathrm{~W} \\
28 \mathrm{mg} / \mathrm{m}^{3}: 60 \mathrm{~W}\end{array}$ & $\begin{array}{l}37.8 \pm 2.4 \\
84.4 \pm 2.4 \\
121.5 \pm 5.4 \\
F=146.7 ; p<0.001\end{array}$ & $\begin{array}{l}124 \pm 25 \\
173 \pm 25 \\
230 \pm 16 \\
F=6.3 ; p<0.05\end{array}$ & $\begin{array}{l}0.32 \pm 0.04 \\
0.20 \pm 0.03 \\
0.19 \pm 0.01 \\
F=8.4 ; p<0.01\end{array}$ \\
\hline
\end{tabular}

\section{Discussion}

Compared with EGEE, ${ }^{7}$ the pharmacokinetics respiratory uptake of EGEE-Ac seem to be more complex. When exposed to concentrations near the present day threshold limit value, retention, atmo spheric clearance, and uptake rate decreased as tho

Table 5 Recovery of expired EGEE-Ac (means \pm SEM for five subjects) 
exposure proceeded. A steady state level seemed to be reached only after three to four hours.

The observation that retention increased when exposure concentration was higher is rather unusual. Depending on the degree of saturation of the metabolic clearance mechanisms, retention is expected at most to remain constant or to decrease. Since the first step in EGEE-Ac metabolism is the conversion to EGEE by (plasma) esterases, ${ }^{6}$ the absorbed EGEEAc has to compete for these enzymes with their normal substrates. With increasing plasma concentrations, EGEE-Ac may compete more favourably for the available esterase. As a consequence, EGEE-Ac may be cleared from the blood at a higher rate resulting in a higher alveolocapillary concentration gradient.

During exercise, the retention of EGEE-Ac increased proportionally to the workload, whereas for EGEE no further increase was noticed after $30 \mathrm{~W} .{ }^{7}$ In the case of EGEE this was interpreted as the result of two counteracting factors-namely, a relative increase in alveolar ventilation and a rise in plasma concentration. $^{715}$ For EGEE-Ac the rise in plasma concentration may be less pronounced when competition for the available plasma esterases is overcome.

For equivalent doses of EGEE and EGEE-Ac, retention of EGEE-Ac was always lower. This may be due to the limited solubility of EGEE-Ac in water $(231 \pm 18 \mathrm{~g} / \mathrm{l})$; EGEE is water soluble at all concentrations.

The rate of uptake of EGEE-Ac increased as exposure concentration or physical workload, or both, increased, the latter being primarily due to an increased pulmonary ventilation rate $\left(\dot{\mathrm{V}}_{\mathrm{E}}\right)$; oxygen pulse, an index of cardiac output, and parameters of distribution volume (height and body fat content) also determined the rate of uptake. Compared with EGEE, the contribution of the latter variables seemed more important and may also be attributable to the limited solubility of EGEE-Ac in water. The positive correlation with the body fat content supports this hypothesis.

The observation of EGEE in samples of mixed expired air during exposure to EGEE-Ac indicates that the first step of EGEE-Ac metabolism is its conversion to EGEE. The calculated half life of appearance at rest agrees well with those of plasma esterase substrates. ${ }^{6}$ The observation that the amount of EGEE expired during steady state conditions correlates more with uptake rate than with exposure concentrations is another indication that increasing levels of EGEE-Ac overcome the competitive inhibition of normal esterase substrates.

Postexposure breath concentrations of EGEE-Ac showed a fast drop during the first minutes after the cessation of exposure. This observation can be assigned mainly to the wash out of the respiratory dead space. The slower decrease observed afterwards may best be described by a regression equation containing two exponential terms, indicating at least two pharmacological compartments involved in the respiratory elimination. Based on the ratio between the preexponential coefficients of the elimination curves after exposures at rest, the second compartment seemed to contribute more to the elimination of EGEE-Ac (ratio $0.36 \pm 0.07$ ) than in the case of EGEE (ratio 0.18 \pm 0.04). ${ }^{7}$ Furthermore, since the total amount of EGEEAc eliminated through the lungs is positively correlated with the body fat content and since EGEE-Ac is a more lipophyllic substance than EGEE, it may be assumed that the adipose tissue will make a larger contribution to this second compartment.

Postexposure breath concentrations increased as the total body uptake increased. Exhaled EGEE-Ac after physical exercise, however, seemed to be higher only during the first $30-60$ minutes of the respiratory elimination. This period coincides with the wash out of the first compartment. Compared with the resting condition, relatively more blood is transported to the muscles during exercise whereas the perfusion of the adipose tissue remains almost constant. ${ }^{16}$ As a consequence, the increased amount of EGEE-Ac absorbed would, for the most part, be conducted to the muscles. After exposure, when the blood perfusion normalises to the resting condition, both compartments are washed out at the same rate as after exposure at rest (as indicated by the same rate constants of the regression equations), but only the first compartment begins elimination at the higher values.

The relative amount of EGEE-Ac recovered from respiratory elimination decreased as uptake increased. This observation again supports the hypothesis of competition for the esterases. Indeed, when the competition becomes more favourable for EGEE-Ac at higher blood concentrations, relatively more EGEE$A c$ is converted to EGEE. The absolute amount of EGEE-Ac eliminated through the lungs accounted for $\leqslant 0.5 \%$ of total body uptake so that respiratory elimination is a minor route of excretion for this EGEE derivative also.

We thank Dr W Goossens from the department of haematology and Dr W Lissens from the Central Laboratory for performing the blood and liver screening tests. The skilful technical help of Ms A Mannaerts, Ms C Van Den Bosch, Mr P Donceel, and Mr J Debout is gratefully acknowledged. We are also indebted to Ms V De Keyser for preparing the manuscript. This work was supported by the Institute of Hygiene and Epidemiology of the Belgian Ministry of Public Health, contract No 11/210-0/1985. 
Requests for reprints to: D Groeseneken, Laboratorium voor Arbeidshygiëne en -toxicologie, Provisorium I, Minderbroedersstraat 17, B - 3000 Leuven, Belgium.

\section{References}

1 Rowe VK, Wolf MA. Derivatives of glycols. In: Clayton GD, Clayton FE, eds. Patty's industrial hygiene and toxicology. 3rd rev. New York: Wiley, 1982:3909-4052.

2 Hardin BD, Lyon JP. Summary and overview: NIOSH symposium on toxic effects of glycol ethers. Environ Health Perspect 1984;57:273-5.

3 Miller RR, Hermann EA, Langvardt PW, McKenna MJ, Schwetz BA. Comparative metabolism and disposition of ethylene glycol monomethyl ether and propylene glycol monomethyl ether in male rats. Toxicol Appl Pharmacol 1983;67:229-37.

4 Foster PMD, Creasy DM, Foster JR, Gray TJB. Testicular toxicity produced by ethylene glycol monomethyl and monoethyl ethers in the rat. Environ Health Perspect 1984;57:207-17.

5 Cheever KL, Plotnick HB, Richards DE, Weigel WW. Metabolism and excretion of 2-ethoxyethanol in the adult male rat. Environ Health Perspect 1984;57:241-8.

6 Guest D, Hamilton ML, Deisinger PJ, DiVincenzo GD. Pulmonary and percutaneous absorption of 2-propoxyethyl acetate and 2-ethoxyethyl acetate in beagle dogs. Environ Health Perspect 1984:57:177-83.

7 Groeseneken D, Veulemans H, Masschelein R. Respiratory uptake and elimination of ethylene glycol monoethyl ether in experimental human exposure. Br J Ind Med 1986;43:544-9.
Groeseneken, Veulemans, Masschelein, Van Vle $\overline{\overline{3}}$

8 Groeseneken D, Veulemans H, Masschelein R. Urinary excreti of ethoxyacetic acid in experimental human exposure to eth ene glycol monoethyl ether. Br J Ind Med 1986:43:615-9.

9 Durnin JVGA, Womersley J. Body fat assessment from to body density and its estimation from skinfold thickness: meatsurements on 481 men and women aged from 16 to 72 years. J Nutr 1974;32:77-97.

10 American Conference of Governmental Industrial Hygienis $\frac{\overline{\bar{\theta}} \text {. }}{\text {. }}$ Threshold limit values for chemical substances in the work en ronment adopted by ACGIH for 1985-6. Cincinnati: ACGIR, 1986.

11 Veulemans H, Masschelein R. Experimental human exposure to toluene. I. Factors influencing the individual respiratory uptake and elimination. Int Arch Occup Environ Health 1978, 42:91-103.

12 Monster AC, Boersma G, Duba WC. Pharmacokinetics of te chloroethylene in volunteers, influence of workload an exposure concentration. Int Arch Occup Environ Healm 1976;38:87-102.

13 Astrand I. Uptake of solvents in the blood and tissues of man. review. Scand J Work Environ Health 1975;1:199-218.

14 Veulemans H, Van Vlem E, Janssens H, Masschelein R, Leplat fu Experimental human exposure to $n$-hexane. Study of the respo ratory uptake and elimination, and of $n$-hexane concentrations in peripheral venous blood. Int Arch Occup Environ Health 1982;49:251-63.

15 Åstrand PO, Rodahl K. Textbook of work physiology. Phy iological bases of exercise. 2nd ed. Vol 7. New York: McGraw Hill Book Company, 1977:227-35.

16 Rowell LB. Human cardiovascular adjustments to exercise ar\& thermal stress. Physiol Rev 1974;54:75-159.

\section{Correspondence and editorials}

The British Journal of Industrial Medicine welcomes correspondence relating to any of the material appearing in the journal. Results from preliminary or small scale studies may also be published in the correspondence column if this seems appropriate. Letters should be not more than 500 words in length and contain a minimum of references. Tables and figures should be kept to an absolute minimum. Letters are accepted on the understanding that they may be subject to editorial revision and shortening.

The journal now also publishes editorials which are normally specially commissioned. The Editor welcomes suggestions regarding suitable topics; those wishing to submit an editorial, however, should do so only after discussion with the Editor. 